\title{
TOXICITY OF AZATHIOPRINE: why and when? Analysis of the prevalence of polymorphism in Joinville, SC, Brazil
}

\author{
Gabriela Roncone GASTAL ${ }^{1}$, Simone MOREIRA², Caroline Furtado NOBLE ${ }^{3}$, \\ Leslie Ecker FERREIRA4 ${ }^{4}$, Paulo Henrique Condeixa de FRANÇA ${ }^{5}$ and Mauro PINHO 5
}

\begin{abstract}
Context - The use of thiopurine drugs such as azathioprine and 6-mercaptopurine has become quite common in the treatment of inflammatory bowel disease, transplantation and acute leukemias. Despite their effectiveness, these drugs are capable of causing drug-induced toxicity with the risk of death by myelosuppression. It is now known that these complications occur because of genetic polymorphisms of the thiopurinemethyltransferase (TPMT) enzyme, responsible for its metabolism. Objective - To assess the prevalence of thiopurine methyltransferase polymorphisms in the population of Joinville, SC, Brazil. Methods - We analyzed the frequency of four main allelic variants of the TPMT gene in 199 blood donors from Joinville, from February to April 2010. Results - The normal allele ("wild-type") was found in 93.9\% of subjects studied. TPMT variants were detected in 12 subjects (6.03\%). Conclusions - From this study, it was estimated at 6\% the risk of toxicity by the administration of azathioprine and 6-mercaptopurine to patients in Joinville.
\end{abstract}

HEADINGS - Azathioprine, toxicity. 6-mercaptopurine, toxicity. Inflammatory bowel diseases. Polymorphism, genetic.

\section{INTRODUCTION}

The use of thiopurine drugs such as azathioprine and 6-mercaptopurine has become quite common in the treatment of inflammatory bowel disease, transplantation and acute leukemias ${ }^{(3,8)}$. Despite their effectiveness, these drugs may cause drug-induced toxicity with risk of death by myelosuppression, even when used in standard doses ${ }^{(16,18)}$. It is now known that these complications occur because of genetic polymorphisms of thiopurine methyltransferase (TPMT) enzyme, responsible for its metabolism ${ }^{(9)}$.

Levels of TPMT activity are controlled by genetic polymorphisms, which are the main responsible factor for individual differences in toxicity and therapeutic efficacy ${ }^{(16)}$. Populational and family studies have shown that patients with low enzymatic activity have a high risk for severe potentially fatal hematologic toxicities $^{(16,18)}$.

Although more than 20 allelic variants of TPMT gene have been published, only three of these, described as $* 2, * 3 \mathrm{~A}$ and $* 3 \mathrm{C}$, account for more than $95 \%$ of reported cases related to myelosuppression ${ }^{(1,12,14)}$. Several studies have been performed in various countries and regions seeking to determine the population prevalence of these polymorphisms to provide a better understanding of risks of administration of thiopurines drugs.

The aim of this study is to identify the prevalence of the most relevant TPMT polymorphisms in the population of Joinville/SC, in order to assess the risk of myelosuppression due to thiopurine drug administration.

\section{METHODS}

Material - We collected 199 samples from blood donors of the Regional Blood Center of Joinville, SC, Brazil, in the period from February to April 2010, by free and informed consent. All subjects were required to live in this city. Exclusion criteria were members of the same family and refusal to sign the informed consent. Based on a total number of 497,331 inhabitants of Joinville, estimated by the IBGE 2000 Census, it was calculated the need of 75 and 200 samples to achieve a $95 \%$ and $99 \%$ confidence interval, respectively.

Methods - Samples were received in Vacutainer tubes (BD) etched with EDTA as an anticoagulant and frozen at $-20^{\circ} \mathrm{C}$ until processing, which included the following steps:

University of Joinville Region (UNIVILLE) - Post-Graduate Program in Health and Environment - Laboratory of Molecular Biology

No interest conflict.

Department of Hematology, Graduate Program in Health and Environment; ${ }^{2}$ Department of Biochemistry, Graduate Program in Health and Environment; ${ }^{3}$ Academic Course of Biological Sciences, Fellow of the Scientific Initiation UNIVILLE; ${ }^{4}$ Master Teacher and Department of Medicine UNIVILLE; ${ }^{5}$ Department of Medicine UNIVILLE, Joinville, SC, Brazil.

Correspondence: Dr. Gabriela Roncone Gastal - Universidade Univille - Caixa postal: 246 - 89201-972 - Joinville, SC, Brazil. E-mail: gabigastal22@gmail.com 
a. Extraction and purification of human genomic DNA using "Qiamp DNA Blood Mini Kit" (Qiagen).

b. Detection of polymorphisms of TPMT genotypes by RFLP (Restriction Fragment Length Polymorphism) techniques, according to the following specifications:

G460A Polymorphism - The pair of primers used were P460F (5'-ATAACAGAGTGGGGAGGCTGC-3') and P460R (5'-CTAGAACCCAGAAAAAGTATAG-3') and amplified a 365 bp segment of exon VII of TPMT gene. The amplicons generated were digested for one hour with MwoI endonuclease (New England Biolabs, Inc. Beverly, MA, USA), according instructions of the suppliers. For the homozygous wild cases, the enzyme cleaves a single site in DNA, generating two fragments, one of $267 \mathrm{pb}$ and another of $98 \mathrm{bp}$. The presence of the G460A substitution eliminates a cutting site ${ }^{(7)}$ (Figure 1A).

Reactions were performed in $50 \mu \mathrm{L}$ volume, using 50-100 ng genomic DNA, 1 U Platinum Taq DNA polymerase (Invitrogen, Carlsbad, USA), 200 mM dNTPs (LGC Biotecnologia, São Paulo, Brazil), $1.5 \mathrm{mM} \mathrm{MgCl}{ }_{2}$ (Invitrogen) and 10 pmol of each primer (Integrated DNA Technologies, Eugene, USA). Thermocycling were performed as described by Yates et al. ${ }^{(18)}$ in LGC XP Cycler machine (Bioer, Tokyo, Japan), consisting of an initial phase at $94^{\circ} \mathrm{C}$ for 3 minutes, followed by 40 cycles involving 1 minute at $94^{\circ} \mathrm{C}$ (denaturation), 2 minutes $55^{\circ} \mathrm{C}$ (pairing) and 1 minute at $72^{\circ} \mathrm{C}$ (extension). A final extension at $72^{\circ} \mathrm{C}$ for 7 minutes was added. Afterwards, the amplicons obtained were subjected to enzymatic digestion with endonuclease $M w o I$. Each reaction was performed using $1 \mathrm{U}$ of enzyme and $5 \mu \mathrm{L}$ of the amplicon. The material was incubated at $37^{\circ} \mathrm{C}$ for 1 hour.

A719G Polymorphism - The primers used were: P719F (5'-AATCCCTGATGTCATTCTTCATAGTATTT-3') and P719R (5'-CAGGCTTTAGCATA-
ATTTTCAATTCCTC-3'), amplifying a 236 bp segment. The amplicons generated were digested for 1 hour with the Accl endonuclease (New England Biolabs, Inc. Beverly, MA, USA), according to instructions of suppliers. The A179G mutation introduces a restriction site for endonuclease actions and, therefore, the mutated version will be detected by observation of two fragments ( 86 and $150 \mathrm{pb})$, while the variant will remain intact wild (236 pb) 7 (Figure 1B).

Reactions were performed in $50 \mu \mathrm{L}$ volume, using 50 100 ng genomic DNA, 1 U Platinum Taq DNA polymerase (Invitrogen), $200 \mathrm{mM}$ dNTPs (LGC Biotecnologia), $1.5 \mathrm{mM}$ $\mathrm{MgCl}_{2}$ (Invitrogen) and $10 \mathrm{pmol}$ of each primer (Integrated DNA Technologies). Thermocycling were performed as described by Yates et al. ${ }^{(18)}$ in LGC XP Cycler machine (Bioer), consisting of an initial phase at $94^{\circ} \mathrm{C}$ for 3 minutes, followed by 40 cycles involving 1 minute at $94^{\circ} \mathrm{C}$ (denaturation), 2 minutes $55^{\circ} \mathrm{C}$ (pairing) and 1 minute at $72^{\circ} \mathrm{C}$ (extension). A final extension at $72^{\circ} \mathrm{C}$ for 7 minutes was added. Afterwards, amplicons were subjected to enzymatic digestion with endonuclease $A c c l$. Each reaction was performed using $1 \mathrm{U}$ of enzyme and $5 \mu \mathrm{L}$ of the amplicon. The material was incubated at $60^{\circ} \mathrm{C}$ for 1 hour.

G238C Polymorphism - To investigate the G238C transversion ARMS PCR was carried out, where two amplification reactions were performed to detect respective allelic variants. Both wild and mutant forms were detected with the use of combinations of primers $\mathrm{P} 2 \mathrm{~W}+\mathrm{P} 2 \mathrm{M}$ and $\mathrm{P} 2 \mathrm{C}+\mathrm{P} 2 \mathrm{C}$, respectively ${ }^{(18)}$. Primers used were P2W - (5'-GTATGATTTTAT GCAGGTTTG-3') and P2C - (5'-TAAATAGGAACCATCGGACAC-3') to amplify a segment of $256 \mathrm{bp}$ of exon V of the normal gene TPMT, and other reaction used the primers P2A (5'-GTATGATTTTATGCAGGTTTC-3') and P2C, which amplify a segment of equal size variant that leads to transversion (Figure 1C) ${ }^{(7)}$.

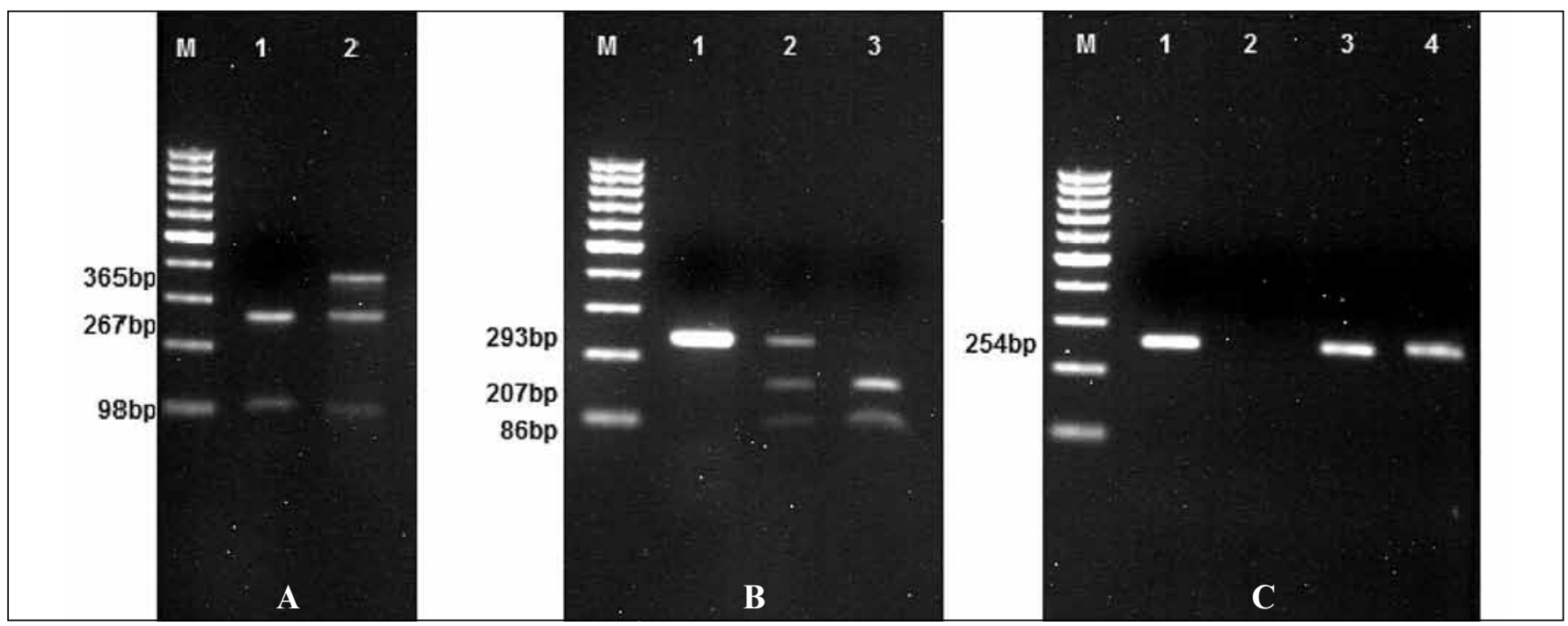

FIGURE 1. Illustrative electrophoretic patterns related to the investigation of polymorphisms of gene TPMT: (A) G460A - 1. genotype TPMT *1/TPMT *1, 2. TPMT *1/TPMT *3B; (B) A719G - 1. genotype TPMT *1/TPMT *1, 2. TPMT *1/TPMT *3C, 3. TPMT *3C/TPMT *3C; and (C) G238C $-1(+)$ and $2(-)$. genotype TPMT *1/TPMT *1, $3(+)$ and $4(+) . T P M T * 1 / T P M T * 2$. (M) molecular size marker $\left(\mathrm{Gene} \mathrm{Ruler}^{\mathrm{TM}} 100\right.$ bp Ladder, Fermentas) 
Amplification reactions were performed in a final volume of $50 \mathrm{~mL}$ in microtubes with a working volume of $200 \mu \mathrm{L}$. Each reaction received approximately 50-100 ng of genomic DNA, 1 U Platinum Taq DNA polymerase (Invitrogen), 200 $\mathrm{mM}$ dNTPs (LGC Biotecnologia), $1.5 \mathrm{mM} \mathrm{MgCl}$ (Invitrogen) and 10 pmol each of the primers (Integrated DNA Technologies, Eugene, USA). Thermocycling were performed as described by Yates et al. ${ }^{(18)}$ in LGC XP Cycler machine (Bioer, Tokyo, Japan), consisting of an initial phase at $94^{\circ} \mathrm{C}$ for 3 minutes, followed by 40 cycles involving 1 minute at $94^{\circ} \mathrm{C}$ (denaturation), 2 minutes at $64^{\circ} \mathrm{C}$ (pairing) and 1 minute at $72^{\circ} \mathrm{C}$ (extension). A final extension at $72^{\circ} \mathrm{C}$ for 7 minutes was added.

Electrophoresis: for confirmation of results, a fraction $(10 \mu \mathrm{L})$ of each PCR or enzymatic digestion $(20 \mu \mathrm{L})$ was subjected to gel electrophoresis on a $1.5 \%$ agarose containing $0.5 \mathrm{mg} / \mathrm{mL}$ of ethidium bromide. Visualization was achieved by exposure to ultraviolet light, followed by photodigitalization (DNR Bioimage Systems, Jerusalem, Israel) and comparison with commercial standard (Gene RulerTM 100bp Ladder Fermentas, Burlington, Canada) and their expected electrophoretic profiles.

For confirmation purposes of genotypic patterns obtained by PCR, representative amplicons were sequenced bidirectionally employing kit Big Dye ${ }^{\circledR}$ Terminator v3.1 and ABI 377 DNA Sequencer (Applied Biosystems). The sequences were analyzed by software ClustalW.

The study was approved by the Ethics Committee of the Univille, Joinville, SC, Brazil.

\section{RESULTS}

In the whole group, 68 subjects were female $(34 \%)$ and $132(66 \%)$ were male. Skin color self-report revealed 14 mixed race $(7 \%), 175$ white $(88 \%)$ and 10 black $(5 \%)$. Average age was 32 years.

Normal or wild genotype (TPMT $* 1 / * 1$ ) was the most frequent $(93.96 \%)$, followed by variants *3A $(3.5 \%), * 3 \mathrm{~B}$ $(1 \%), 2(1 \%)$ and $* 3 \mathrm{C}(0.5 \%)$.

Twelve subjects showed allelic variant of the TPMT gene $(6.03 \%)$, in eight men and four women. All polymorphisms detected were found in self-declared white skin subjects.

When polymorphisms were assessed separately, G460A polymorphism was found in nine subjects $(4.5 \%), \mathrm{A} 719 \mathrm{G}$ polymorphism in eight subjects (4\%) and G238C polymorphism in two subjects (2\%) (Figure 1).

Genotypes frequency is shown on Table 1.

TABLE 1. Main clinical and laboratorial myelotoxicity features

\section{6-MP myelotoxicity features}

\section{Thrombocytopenia}

Granulocytopenia

Anemia

Anorexia

Nausea

Vomiting

High transaminases levels

Cholestatic jaundice
Genotyping profiles were confirmed by sequencing of amplicons.

\section{DISCUSSION}

The large number of patients currently treated by azathioprine or 6-mercaptopurine emphasizes the risk of complications, since these antimetabolites drugs interfere with the availability of precursors of purine nucleotides by competing with them in the synthesis of DNA or RNA. Its primary pharmacological action is due to the incorporation of the active metabolite in cells DNA (6-thioguanine (6TGN) nucleotide). Its primary route of metabolism is due to the action of the enzyme thiopurine methyltransferase ${ }^{3-5}$, whose activity levels are controlled by a common genetic polymorphism. The existence of this polymorphism generates allelic variants of TPMT phenotype which decreased ability in S-methylation of thiopurines, with consequent increase in active metabolites (6-TGN), leading to a greater pharmacological activity, but associated to a higher risk of adverse effects ${ }^{(7,11,12)}$.

The main adverse effect of 6-MP is myelotoxicity, which develops gradually. Thrombocytopenia, granulocytopenia or anemia may be observed for several weeks during maintenance treatment. In those cases, discontinuation of treatment is usually associated with a fast marrow recovery. Gastrointestinal effects such as anorexia, nausea and vomiting are infrequent in children ${ }^{(8)}$. Hepatotoxicity may occur with increased levels of transaminases and cholestatic jaundice and should also subside with drug withdrawal. These main clinical and laboratorial features are summarized in Table 1.

Several studies have shown that hepatotoxicity seems to be related to the accumulation of methylated metabolites such as metilmercaptopurina. These findings were observed more frequently in patients with high TPMT activity ${ }^{(2,5)}$.

Several studies have demonstrated that patients with the exceptionally low TPMT activity are at higher risk of developing hematological toxicity, i.e., serious pancytopenia and sometimes fatal, due to the accumulation of cytotoxic metabolites after treatment with conventional doses of thiopurines, while patients with higher levels of activities did not present this complication ${ }^{(3,4)}$.

Therefore, patients with TPMT deficiency can present severe toxicity even when receiving standard doses of these medications. To avoid this complication, patients with low enzyme activity should receive an adjusted dose of $1 / 10$ to $1 / 15$ of the standard dose with subsequent careful monitoring ${ }^{(1)}$.

Although TPMT deficiency can also be measured by its activity in erythrocytes, measurement of enzyme activity may be unreliable in individuals who had previously received transfusions of red blood cells within 2 to 3 months $^{(18)}$ or in use of other drugs such as olsalazine ${ }^{(17)}$ and sulfasalazine. So, genotyping is a clinically relevant and reliable method to determine the myelosuppression risk.

A meta-analysis recently published ${ }^{(6)}$ assessed the risk of myelosuppression in patients with TPMT intermediate 
TABLE 2. Frequency distribution of TPMT alleles (\%) in various populations (Efrati et al. ${ }^{(16)}$ )

\begin{tabular}{lcccccc}
\hline Population & $* 2$ & $* 3 \mathrm{~A}$ & $*^{*} 3 \mathrm{~B}$ & $*^{3} \mathrm{C}$ & $\mathbf{N}^{\mathrm{o}}$. & $\begin{array}{c}\text { Haplotype } \\
\text { frequency }\end{array}$ \\
\hline Sardinians & 1.7 & 0.5 & 0.3 & 0.7 & 259 & 3.4 \\
Swedish & 0.0 & 3.7 & 0.1 & 0.4 & 800 & 4.3 \\
Polish & 0.4 & 2.7 & 0 & 0.1 & 358 & 3.2 \\
Slovenian & 0 & 40.1 & 0.3 & 0.5 & 194 & 4.9 \\
Argentine & 0.7 & 3.1 & 0 & 0 & 147 & 3.8 \\
French & 0.7 & 3 & 0 & 0.4 & 304 & 4.1 \\
Italian & 0.4 & 3.8 & 0 & 0.9 & 103 & 5.3 \\
Colombian & 0.3 & 3.5 & 0 & 0 & 140 & 3.9 \\
British & 0.5 & 4.5 & 0 & 0.2 & 199 & 5.2 \\
German & 0.2 & 4.4 & 0 & 0.4 & 1214 & 5 \\
Portuguese & 1.1 & 2.4 & 0 & 0.7 & 310 & 4.2 \\
American Caucasian & 0.2 & 3.2 & 0 & 0.2 & 282 & 3.6 \\
African American & 0.4 & 0.8 & 0 & 2.4 & 248 & 3.6 \\
Egyptian & 0 & 0.3 & 0 & 1.3 & 200 & 1.6 \\
Mozambican & 0 & 0.2 & 0 & 3.8 & 250 & 4 \\
Ghanaian & 0 & 0 & 0 & 7.6 & 217 & 7.6 \\
Chinese & 0 & 0 & 0 & 1.3 & 225 & 1.3 \\
West Asia & 0 & 1 & 0 & 0 & 99 & 1 \\
Uygur Chinese & 0 & 0.3 & 0 & 1.6 & 160 & 1.9 \\
Taiwanese & 0 & 0 & 0 & 0.6 & 249 & 0.6 \\
Japanese & 0 & 0 & 0 & 0.8 & 192 & 0.8 \\
Jews & 0 & 0.7 & 0 & 0 & 531 & 0.7 \\
Molesms & 0 & 0.7 & 0 & 1.0 & 0194 & 1.8 \\
Druze & 0 & 3.1 & 0 & 0.7 & 156 & 3.9 \\
\hline
\end{tabular}

activity and found an odds ratio for developing leucopenia of 4.19 (95\% CI: 3.20-5.48), suggesting that individuals with intermediate or absence of the enzyme have an increased risk of developing drug-induced myelosuppression compared with individuals with normal activity.

Weinshilboum and Sládek ${ }^{(17)}$ showed a trimodal distribution of thiopurine methyltransferase activity in red blood cells. In this study, 298 patients $(88.6 \%)$ had high enzyme
TABLE 3. Frequency of genotypes in the population of Joinville

\begin{tabular}{|c|c|c|}
\hline TPMT Genotype & Subjects & Frequency $\%$ \\
\hline$T P M T * 1 / * 1$ & 187 & $93.96(89.97-96.69)$ \\
\hline$T P M T * 1 / * 2$ & 02 & $1.0(0.16-3.28)$ \\
\hline$T P M T * 1 / * 3 A$ & 07 & $3.51(1.55-6.83)$ \\
\hline$T P M T * 1 / * 3 B$ & 02 & $1.0(0.16-3.28)$ \\
\hline$T P M T * 1 / * 3 C$ & 01 & $0.5(0.025-2.45)$ \\
\hline TOTAL & 199 & $100 \%$ \\
\hline
\end{tabular}

activity, $11 \%$ had intermediate activity and $0.3 \%$ of subjects showed no detectable activity.

In an extensive review, Efrati et al. ${ }^{(4)}$ have compared the rate of frequency distribution of TPMT alleles $(\%)$ in various populations, as demonstrated on Table 2 .

In present study, from 12 subjects with allelic variants, TPMT *3A was identified in $58.33 \%$ of the variants, TPMT *3B $(16.6 \%)$, TPMT *3C $(8.33 \%)$ and TPMT *2A $(16.6 \%)$ (Table 3).

The prevalence of TPMT polymorphisms in the population of Joinville was $6.03 \%$. The population in this city is composed by more than $90 \%$ of white people (according to IBGE), confirming the high prevalence of polymorphism *3A, more prevalent in Caucasian population, and low prevalence of polymorphism *3C, usually found in black people.

Despite similar report from Silva et al. ${ }^{(13)}$, three other studies $^{(2,5,10)}$ have obtained different results, where TPMT alleles $* 2$ and $* 3 \mathrm{C}$ were most frequent. These differences may be related to variation of radical distribution among Brazilian regions. According to IBGE's 2000 census, Brazilian population is composed by $53.74 \%$ white, so that Joinville racial profile is very different from the rest of the country. The other studies took place in Minas Gerais and Rio de Janeiro, where racial distribution is more compatible to average Brazilian population.

The study of the prevalence of TPMT gene polymorphism in Joinville has provided us a better understanding of the genetic profile of the local population. We concluded the risk of toxicity by the administration of azathioprine and 6-mercaptopurine to patients in Joinville is estimated at 6\%.

Gastal GR, Moreira S, Noble CF, Ferreira LE, França PHC, Pinho M. Toxicidade da azatioprina: por que e quando? Análise da prevalência de polimorfismo em Joinville, SC. Arq Gastroenterol. 2012;49(2):130-4.

RESUMO - Contexto - A utilização de drogas tiopurinas como a azatioprina e a 6-mercaptopurina tem se tornado bastante frequente no tratamento de doenças inflamatórias intestinais, transplantes e leucemias agudas. Apesar de sua efetividade, estas drogas são capazes de causar toxicidade drogainduzida com risco de morte através de mielossupressão. Sabe-se hoje que estas complicações ocorrem em decorrência de polimorfismos genéticos da enzima tiopurina metiltransferase (TPMT), responsável por sua metabolização. Objetivos - Avaliar a prevalência do polimorfismo do gene da TPMT na população de Joinville, SC. Métodos - Foi analisada a frequência das quatro principais variantes alélicas do gene da TPMT em 199 doadores de sangue da cidade de Joinville, SC, no período de fevereiro a abril de 2010. Resultados - O alelo normal ("selvagem") foi encontrado em 93,9\% dos indivíduos estudados. Variantes da TPMT foram detectadas em 12 sujeitos (6,03\%). Conclusões - A partir do presente estudo, pode-se estimar em cerca de $6 \%$ o risco de toxicidade na administração de azatioprina e 6-mercaptopurina a pacientes em Joinville.

DESCRITORES - Azatioprina, toxicidade. 6-mercaptopurina, toxicidade. Doenças inflamatórias intestinais. Polimorfismo genético. 


\section{REFERENCES}

1. Alvarez LL, Venegas MS, Larrondo LM, Becerra NB, Castro AL, Quera RP. Thiopurine S-methyltransferase gene polymorphism in Chilean blood donors. Rev Med Chil. 2009;137:185-92.

2. Boson WL, Romano-Silva MA, Correa H, Falcao RP, Teixeira-Vidigal PV, De Marco L. Thiopurine methyltransferase polymorphisms in a Brazilian population. Pharmacogenomics J. 2003;3:178-82.

3. Coulthard S, Hogarth L. The thiopurines: an update. Invest New Drugs. 2005;23:523-32.

4. Efrati E, Adler L, Krivoy N, Sprecher E. Distribution of TPMT risk alleles for thioupurine toxicity in the Israeli population. Eur J Clin Pharmacol. 2009;65: 257-62.

5. Fraga AO, Coutinho PC, Hatagima A. Resumos do $55^{\circ}$ Congresso Brasileiro de Genética. Centro de Convenções do Hotel Monte Real Resort. Águas de Lindóia, SP, Brasil, 2009.

6. Higgs JE, Payne K, Roberts C, Newman WG. Are patient with intermediary TPMT activity at increased risk of myelossupression when taking thiopurine medications? Pharmacogenomics. 2010;11:177-88.

7. Krynetski EY, Schetz JD, Galpin AJ, Pui CH, Relling MV, Evans WE. A single point leading to loss of catalytic activity in human thiopurine S-methyltransferase. Proc Natl Acad Science USA. 1995;92:949-53.

8. Lennard L, Lilleyman JS, Loon JV, Weinshilboum RM. Genetic variation in response to 6-mercaptopurine for childhood acute lymphoblastic leukaemia. Lancet. 1990;336:225-9.

9. Otterness D, Szumlanski C, Lennard L, Klemetsdal B, Aarbakke J, Park-Hah JO, Iven H, Schmiegelow K, Branum E, O'Brien J, Weinshilboum R. Human thiopurine methyltransferase pharmacogenetics: gene sequence polymorphisms. Clin. Pharmacol Ther. 1997;62:60-73.

10. Reis M, Santoro A, Sauarez-Kurtz G. Thiopurine methyltransferase phenottypes and genotypes in Brazilians. Pharmacogenetics. 2003;13:371-3.
11. Sahasranaman S, Howard D, Roy S. Clinical pharmacology and pharmacogenetics of thiopurines. Eur J Clin Pharmacol. 2008;64:753-67.

12. Salavaggione OE, Wang L, Wiepert M, Yee VC, Weinshilboum RM. Thiopurine S-methyltransferase pharmacogenetics: variant allele functional and comparative genomics. Pharmacogenet Genomics. 2005;15:801-15.

13. Silva MR, de Oliveira BM, Viana MB, Murao M, Romanha AJ. Thiopurine Smethyltransferase (TPMT) gene polymorphism in Brazilian children with acute lymphoblastic leukemia: association with clinical and laboratory data. The Drug Monit. 2008;30:700-4.

14. Szumlanski C, Otterness D, Her C, Lee D, Brandriff B, Kessell D, Spurr N, Lennard L, Wieben E, Weinshilboum R. Thiopurine methyltransferase pharmacogenetics: human gene cloning and characterization of a common polymorphism. DNA Cell Biol. 1996;15:17-30.

15. Tai HL, Krynetski EY, Yates CR, Loennechen T, Fessing MY, Krynetskaia NF, Evans WE. Thiopurine S-methyltransferase deficiency: two nucleotide transitions define the most prevalent mutant allele associated with loss of catalytic activity in caucasians. Am J Hum Genet. 1996;58:694-702.

16. Wang L, Weinshilboum R. Thiopurine S-methyltransferase pharmacogenetics: insights, challenges and future directions. Oncogene. 2006;25:1629-38.

17. Weinshilboum RM, Sladek SL. Mercaptopurine pharmacogenetics: monogenetic inheritance of erythrocyte thiopurine methyltransferase activity. Am J Hum Genet. 1980;32:651-62.

18. Yates CR, Krynetski EY, Loennechen T, Fessing MY, Tai HL, Pui CH, Relling MV, Evans WE. Molecular diagnosis of thiopurine S-methyltransferase deficiency: genetic basis for azathioprine and mercaptopurine intolerance. Ann Intern Med. 1997;126:608-14.

19. Zhou S. Clinical pharmacogenomics of thiopurine S-methyltransferase. Curr Clin Pharmacol. 2006;1:119-28.

Received 29/9/2011 Accepted 30/11/2011. 